\title{
Pengaruh Komunikasi Dan Kualitas Pelayanan Terhadap Kinerja Perawat Di Rumah Sakit Bhayangkara Palembang
}

\section{Hendra Hadiwijaya*}

${ }^{1}$ Palcomtech Polytechnic

\section{A R T I C L E I N F O}

Article history:

Received 10 May 2018

Received in revised form

17 June 2018

Accepted 12 July 2018

Available online 26 August 2018

Kata Kunci:

Komunikasi, Kualitas

layanan, Kinerja.

Keywords:

Communication,Service quality,Performance.

\begin{abstract}
A B S T R A K
Penelitian ini bertujuan untuk mengetahui dan menganalisis pengaruh komunikasi dan kualitas layanan terhadap kinerja perawat di Rumah Sakit Bhayangkara Palembang. Sampel penelitian adalah perawat Rumah Sakit Bhayangkara Palembang sebanyak 110 responden dengan menggunakan metode purposive sampling. Analisis penelitian ini menggunakan Structural Equation Modeling (SEM), yang dioperasikan melalui Lisrel Program. Hasil penelitian menunjukkan bahwa Variabel Komunikasi dan Kualitas Layanan memiliki pengaruh positif dan signifikan terhadap Kinerja Rumah Sakit Perawat Bhayangkara Palembang. Variabel Komunikasi lebih dominan pengaruhnya terhadap Kinerja Rumah Sakit Perawat Bhayangkara Palembang dalam perbandingan variabel kualitas pelayanan
\end{abstract}

A B S T R A C T

This study aims to determine and analyze the influence of communication and service quality on the performance of nurses at Bhayangkara Hospital Palembang. Sample of research is nurse of Bhayangkara Palembang Hospital counted 110 respondents by using purposive sampling method. The analysis of this research using Structural Equation Modeling (SEM), which is operated through Lisrel Program. The results showed that Communication Variables and Service Quality have a positive and significant impact on the Performance of Nurse Hospital Bhayangkara Palembang. Communication Variables more dominant influence on the Performance of Nurse Hospital Bhayangkara Palembang in comparison of service quality variable.

\footnotetext{
* Corresponding author.

E-mail addresses: hendra_hadi@palcomtech.ac.id (Hendra Hadiwijaya)
} 


\section{Pendahuluan}

Komunikasi merupakan suatu transaksi, proses simbolik yang menghendaki orang-orang mengatur lingkungannya dengan membangun hubungan antar sesama manusia melalui pertukaran informasi untuk menguatkan sikap dan tingkah laku orang lain serta berusaha mengubah sikap dan tingkah laku itu sendiri (Cangara 2007). Komunikasi dapat diartikan sebagai proses penyampaian informasi atau pengiriman kepada penerima informasi (Rivai 2006). Dalam hal ini menerima informasi harus memahami isi informasi yang diterima, sebaliknya apabila penerima informasi tidak memahami isi informasi yang diberikan oleh pemberi informasi, berarti tidak terjadi komunikasi yang efektif yang pada akhirnya dapat menimbulkan konflik. Kegagalan organisasi seringkali disebabkan karena kurang efektifnya proses komunikasi yang terjadi dalam organisasi. komponen komunikasi yaitu: Sumber, Pesan, Saluran, Penerima, Umpan balik, komunikator dan gangguan (Robbins 2008).

Kualitas pelayanan adalah memberikan kesempurnaan pelayanan untuk tercapainya keinginan atau harapan pelanggan,(Hadiwijaya 2017b; Normasari 2013). Kualitas pelayanan terdiri dari lima dimensi, yaitu : keandalan, daya tanggap, jaminan, kemudahan akses, dan penampilan fisik. Dengan kata lain, faktor utama yang mempengaruhi kualitas pelayanan adalah pelayanan yang diharapkan wajib pajak dan persepsi masyarakat terhadap pelayanan tersebut. Nilai kualitas pelayanan tergantung pada kemampuan instansi dan pegawainya dalam memenuhi harapan wajib pajak secara konsisten, (Hadiwijaya 2017b; Nugroho 2014). pelayanan merupakan suatu tindakan atau kegiatan yang ditawarkan oleh satu pihak kepada pihak lain, pada dasarnya tidak berwujud dan tidak mengakibatkan kepemilikan apapun, (Kotler 2000; Marismiati and Hadiwijaya 2013). Menurut Lovelock pelayanan/jasa dapat diklasifikasikan berdasarkan lima kriteria, yaitu: a). Berdasarkan sifat tindakan jasa. b). Berdasarkan hubungan dengan pelanggan. c).. Berdasarkan tingkat customization dan judgement dalam penyampaian jasa. d). Berdasarkan sifat permintaan dan penawaran jasa. e. Berdasarkan metode penyampaian jasa, (Hadiwijaya 2011; Tjiptono 2000). Perawat sebagai petugas yang selalu berhubungan dengan pasien harus memiliki banyak ketrampilan, salah satunya adalah ketrampilan interpersonal yaitu ketrampilan dalam berkomunikasi dengan pasien (Suhaila, 2017)

Kinerja adalah hasil kerja yang dapat dicapai oleh seseorang atau sekelompok orang dalam suatu organisasi kerja yang dapat dicapai oleh seseorang atau sekelompok orang dalam suatu organisasi, sesuai dengan tanggung jawab masing-masing, dalam rangka upaya mencapai tujuan organisasi bersangkutan secara sah, tidak melanggar hukum dan sesuai dengan moral maupun etika. Ada beragam kriteria yang digunakan dalam pengukuran kinerja pegawai, (Hadiwijaya 2015; Suyadi Prawirosentono 2001). Kinerja pada dasarnya adalah "apa yang dilakukan atau tidak dilakukan oleh karyawan". Kinerja adalah hasil atau tingkat keberhasilan seseorang secara keseluruhan selama periode tertentu di dalam melaksanakan tugas dibandingkan dengan berbagai kemungkinan, seperti standar hasil kerja, target atau sasaran atau kriteria yang telah ditentukan terlebih dahulu dan telah disepakati bersama.(Hadiwijaya 2017a; Mathis and Jackson 2006). Kinerja dapat dinilai atau diukur dengan beberapa indikator yaitu: a). Efektifitas, Tanggung jawab, Disiplin dan Inisiatif, (Hadiwijaya 2016; Suryadi Prawirosentono 2008)

Rumah Sakit Bhayangkara Palembang merupakan Rumah Sakit milik Polri dibawah komando Polda Sumatera Selatan yang beroperasi sejak tahun 1989. yang melayani pelayanan Kedokteran dan Kepolisian, dukungan kesehatan dalam melaksanakan tugas fungsi pelayanan kesehatan bagi pegawai negeri pada Polri, keluarga dan masyarakat umum. Dalam menyelesaikan pekerjaan dengan cepat, jadwal kerja yang tidak dapat diprediksi dan perawat juga sering mendapat tanggung jawab yang besar pada kelangsungan hidup pasien yang seringkali berada pada masa kritis. Dibutuhkan komunikasi yang baik bagi perawat terhadap pasien dan perawat terhadap atasannya. Selain itu juga harus tetap mengutamakan kualitas pelayanan sehingga pasien merasa tidak terbengkalaikan. Sehingga kinerja perawat dalam melaksanakan tugasnya sesuai standar hasil kerja yang telah ditetapkan Rumah Sakit Bhayangkara Palembang

\section{Metode}

Sample penelitian adalah perawat Rumah Sakit Bhayangkara Palembang sebanyak 110 responden dengan menggunakan metode purposive sampling.Analisis penelitian ini menggunakan Structural Equation Modelling (SEM), yang dioperasikan melalui Program Lisrel. Kelebihan lain dari metode SEM, adalah dapat menganalisis multivariant secara bersamaan." Sedangkan tujuan penggunaan multivariant adalah untuk memperluas kemampuan, dalam menjelaskan penelitian dan efisiensi statistic (Ferdinand 2005).

\section{Persamaan struktural}




\section{Endogenous Variable $=$ Exogenous Variable + Endogenous Variable + Error}

Indeks pengujian kelayakan model pada penelitian yang menggunakan metode analisis SEM adalah sebagai berikut :

Table 1. Goodness of Fit Index

\begin{tabular}{|c|c|c|c|}
\hline No & Goodness of Fit Index & Cut off Value & Criteria \\
\hline \multirow[b]{2}{*}{1.} & Chi-Square & $<\boldsymbol{\alpha . d f}$ & \multirow{2}{*}{$\begin{array}{l}\text { Good Fit } \\
\text { Marginal fit }\end{array}$} \\
\hline & Probability & $\begin{array}{l}>0.05 \\
0.01-0.05\end{array}$ & \\
\hline 2. & RMSEA & $\begin{array}{l}\leq 0.08 \\
0.08-0.10\end{array}$ & $\begin{array}{l}\text { Good Fit } \\
\text { Marginal Fit }\end{array}$ \\
\hline 3. & NFI & $\begin{array}{l}\geq 0.90 \\
0.80-0.89\end{array}$ & $\begin{array}{l}\text { Good Fit } \\
\text { Marginal Fit }\end{array}$ \\
\hline 4. & NNFI & $\begin{array}{l}\geq 0.90 \\
0.80-0.89\end{array}$ & $\begin{array}{l}\text { Good Fit } \\
\text { Marginal Fit }\end{array}$ \\
\hline 5. & CFI & $\begin{array}{l}\geq 0.90 \\
0.80-0.89\end{array}$ & $\begin{array}{l}\text { Good Fit } \\
\text { Marginal Fit }\end{array}$ \\
\hline 6. & IFI & $\begin{array}{l}\geq 0.90 \\
0.80-0.89\end{array}$ & $\begin{array}{l}\text { Good Fit } \\
\text { Marginal Fit }\end{array}$ \\
\hline 7. & GFI & $\begin{array}{l}\geq 0.90 \\
0.80-0.89\end{array}$ & $\begin{array}{l}\text { Good Fit } \\
\text { Marginal Fit }\end{array}$ \\
\hline 8. & AGFI & $\begin{array}{l}\geq 0.90 \\
0.80-0.89\end{array}$ & $\begin{array}{l}\text { Good Fit } \\
\text { Marginal Fit }\end{array}$ \\
\hline
\end{tabular}

\section{Hasil dan pembahasan}

\section{Confirmatory Factor Analysis (CFA)}

Analisis faktor konfirmatori (CFA) dirancang untuk menguji unidimensionalitas darisuatu konstruk teoritis. Analisis ini sering juga disebut menguji validitas suatu konstruk teoritis. Untuk menguji validitas dimensi dari konstruk dalam penelitian ini dilakukan dengan cara melihat nilai mutan faktor standar dari masing-masing indikator dalam model keseluruhan (Ful Model). Indikator dinyatakan valid apabila memiliki nilai muatan faktor standar lebih besar dari 0,5 dan Tingkat reliabilitas yang diterima adalah apabila nilai Construct Reliability $\geq 0,7$.

\section{a). Confirmatory Factor Analysis (CFA) untuk Konstruk Eksogen}

Pengukuran model untuk menguji validitas indikator-indikator pembentuk konstruk laten dilakukan dengan cara melihat nilai muatan faktor standar dari masing-masing indikator dalam model. Model CFA Konstruk Eksogen dapat dilihat pada Gambar 1:

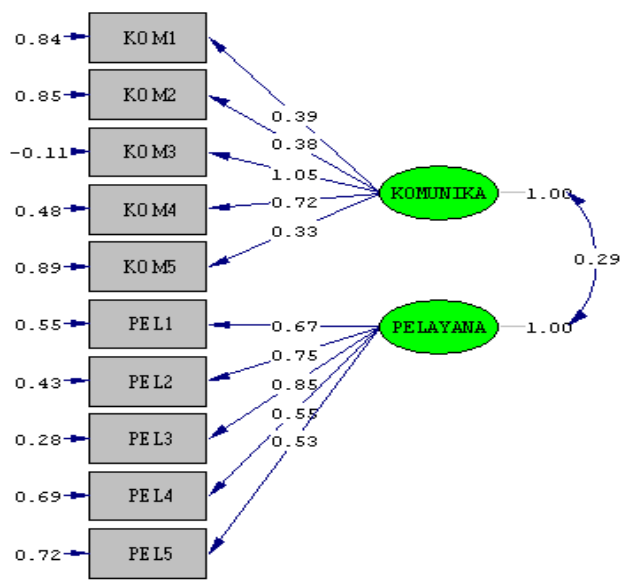

Gambar 1. Model_1 CFA Exogenous Construct. 
Gambar 1. Menunjukan Diagram jalur dalam Model CFA Konstruk Eksogen masih terdapat nilai muatan faktor loading yang kurang dari 0,5, yaitu Pada Variabel Komunikasi pada indikator KOM1, KOM2 dan KOM5, artinya indikator tersebut masih belum valid dan harus dikualarkan. Sehingga diperoleh Model_2 CFA Konstruk Eksogen :

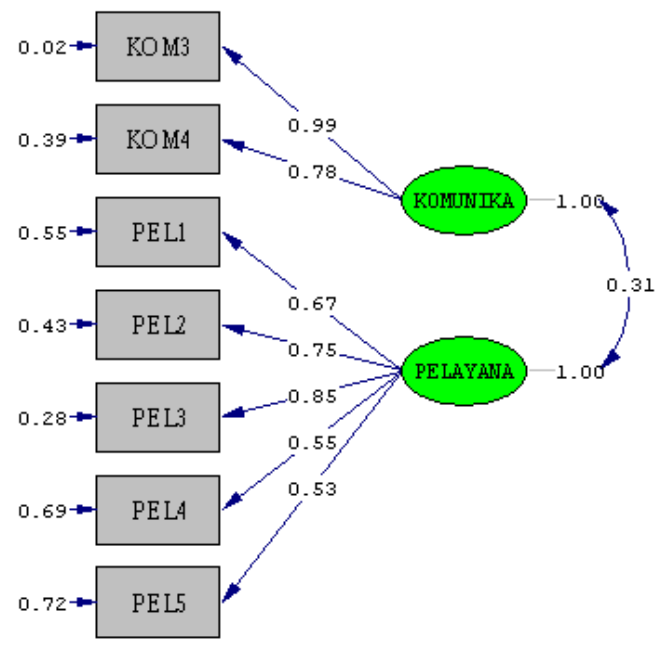

\section{Gambar 2. Model_2 CFA Exogenous Construct}

Pada Gambar 2, mengindikasikan bahwa pada Model_2 CFA Konstruk Eksogen sudah tidak terdapat nilai muatan faktor loading yang kurang dari 0,5, sehingga semua indikator pada variabel Eksogen Variabel Komunikasi dan variabel Pelayanan sudah menunjukkan valid. Hasil perhitungan reliabilitas dengan Construct Reliability dari Analisis Faktor Konfirmatori (Confirmatory Faktor Analysis) / CFA variabel endogen terlihat seperti pada Tabel 2.

Table 2. Uji Validitas dan Reliabilitas Variabel Komunikasi dan variabel Pelayanan

\begin{tabular}{|c|c|c|c|c|}
\hline Dimension & Indicator & $\lambda$ & Error $=1-\lambda^{2}$ & $\mathrm{CR}=(\Sigma \lambda)^{2} /\left((\Sigma \lambda)^{2}+\sum\right.$ Error $)$ \\
\hline \multirow[b]{2}{*}{ Komunikasi } & KOM3 & 0,99 & 0,02 & \multirow[b]{2}{*}{0.884} \\
\hline & KOM4 & 0,78 & 0,39 & \\
\hline \multirow{5}{*}{ Pelayanan } & PEL1 & 0,67 & 0,55 & \multirow{5}{*}{0.808} \\
\hline & PEL2 & 0,75 & 0,43 & \\
\hline & PEL3 & 0,85 & 0,28 & \\
\hline & PEL4 & 0,55 & 0,69 & \\
\hline & PEL5 & 0,53 & 0,72 & \\
\hline
\end{tabular}

Berdasarkan Tabel 2 menunjukan bahwa nilai Construct Reliability (CR) dari seluruh konstruk eksogen diatas 0,7. Dengan demikian dapat disimpulkan bahwa seluruh dimensi dan varibel penelitian dalam Ful Model memiliki reliabilitas dan validitas yang baik

\section{b). Confirmatory Factor Analysis (CFA) untuk Konstruk Endogen \\ Model CFA Konstruk Eksogen dapat dilihat pada Gambar 4:}




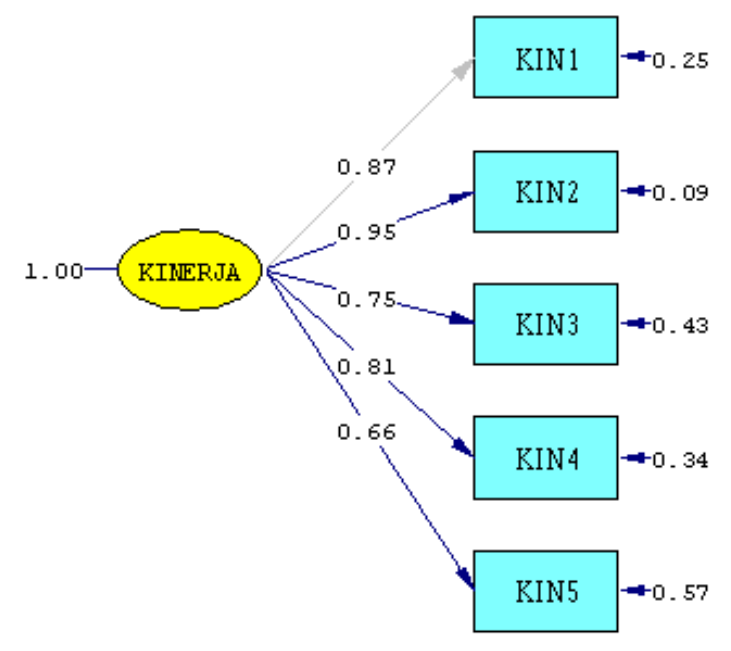

Gambar 3. Model_1 CFA Endogenous Construct

Berdasarkan Gambar 3, mengindikasikan bahwa pada Model_1 CFA Endogenous Construct tidak terdapat nilai muatan faktor loading yang kurang dari 0,5, sehingga indikator pada variabel Endogen sudah menunjukkan valid. Hasil perhitungan reliabilitas dengan Construct Reliability dari Confirmatory Faktor Analysis / CFA variabel endogen terlihat seperti pada Tabel 3.

Table 3. Uji Validitas dan Reliabilitas Variabel Kinerja

\begin{tabular}{ccrrr}
\hline Dimensi & Indicator & \multicolumn{1}{c}{$\boldsymbol{\lambda}$} & Error $=\mathbf{1}-\boldsymbol{\lambda}^{2}$ & $\mathbf{C R}=(\Sigma \lambda)^{2} /\left((\Sigma \lambda)^{2}+\sum\right.$ Error $)$ \\
\hline \multirow{6}{*}{ Kinerja } & KIN1 & 0,87 & 0,25 & \\
& KIN2 & 0,95 & 0,09 & \\
& KIN3 & 0,75 & 0,43 & $\mathbf{0 . 9 0 7}$ \\
& KIN4 & 0,81 & 0,34 & \\
& KIN5 & 0,66 & 0,57 & \\
& KIN1 & 0,87 & 0,25 & \\
& KIN2 & 0,95 & 0,09 & \\
\hline
\end{tabular}

Berdasarkan Gambar 3. dan Tabel 3, mengindikasikan bahwa pada Model_1 CFA Konstruk Endogen tidak terdapat nilai muatan faktor loading yang kurang dari 0,5 , sehingga menunjukan semua indikator pada variabel endogen (Kinerja) sudah valid. Sedangkan nilai Construct Reliability (CR) pada variabel Kinerja menunjukkan bahwa dari seluruh konstruk eksogen $>0,7$. Dengan demikian dapat disimpulkan bahwa seluruh dimensi dan varibel Kinerja penelitian dalam Ful Model memiliki reliabilitas yang baik.

\section{Structural Equation Modelling (SEM) Analysis}

Analisis Structural Equation Modelling (SEM) secara full model dalam menguji kelayakan model secara keseluruhan dilakukan dengan memperhatikan hasil Goodness of Fit yang merujuk pada kriteria model fit yang terdapat pada Table 4 Goodness Of Fit Index:

Table 4. Goodness of Fit Index

\begin{tabular}{llllll}
\hline No & $\begin{array}{l}\text { Goodness of Fit } \\
\text { Index }\end{array}$ & Value & Cut off Value & Criteria & Information \\
\hline & Chi-Square & 214,10 & $<\boldsymbol{\alpha}$.df & Good Fit & Good Fit \\
1. & Probability & 0.000 & $>0.05$ & Marginal fit & \\
& & & $0.01-0.05$ & Good Fit & Good Fit \\
2. & RMSEA & 0.017 & $0.08-0.10$ & Marginal Fit & Good Fit \\
3. & NFI & 0.90 & $\geq 0.90$ & Good Fit & \\
\hline
\end{tabular}




\begin{tabular}{|c|c|c|c|c|c|}
\hline No & $\begin{array}{l}\text { Goodness of Fit } \\
\text { Index }\end{array}$ & Value & Cut off Value & Criteria & Information \\
\hline 4. & NNFI & 0.95 & $\begin{array}{l}0.80-0.89 \\
\geq 0.90 \\
0.80-0.89\end{array}$ & $\begin{array}{l}\text { Marginal Fit } \\
\text { Good Fit } \\
\text { Marginal Fit }\end{array}$ & Good Fit \\
\hline 5. & CFI & 0.90 & $\begin{array}{l}\geq 0.90 \\
0.80-0.89\end{array}$ & $\begin{array}{l}\text { Good Fit } \\
\text { Marginal Fit }\end{array}$ & Good Fit \\
\hline 6. & IFI & 0.90 & $\begin{array}{l}\geq 0.90 \\
0.80-0.89\end{array}$ & $\begin{array}{l}\text { Good Fit } \\
\text { Marginal Fit }\end{array}$ & Good Fit \\
\hline 7. & GFI & 0.91 & $\begin{array}{l}\geq 0.90 \\
0.80-0.89\end{array}$ & $\begin{array}{l}\text { Good Fit } \\
\text { Marginal Fit }\end{array}$ & Good Fit \\
\hline 8. & AGFI & 0.90 & $\begin{array}{l}\geq 0.90 \\
0.80-0.89\end{array}$ & $\begin{array}{l}\text { Good Fit } \\
\text { Marginal Fit }\end{array}$ & Good Fit \\
\hline
\end{tabular}

Berdasarkan Table 4. Goodness of Fit Index dan hasil analisis menunjukan bahwa model secara keseluruhan baik, sehingga dapat dilanjutkan dalam analisis Pengaruh Komunikasi dan Pelayanan terhadap Kinerja.

\section{Statistik Inferensial : SEM}

Analisis ini digunakan untuk menguji hipotesis penelitian yang telah ditetapkan dengan menggunakan data sampel yang diperoleh. Metode Statitik Inferensial yang digunakan dalam analisis data penelitian ini adalah Structural Equation Modeling (SEM). Analisis full model SEM berdasarkan t-value ditampilkan pada Gambar 4:

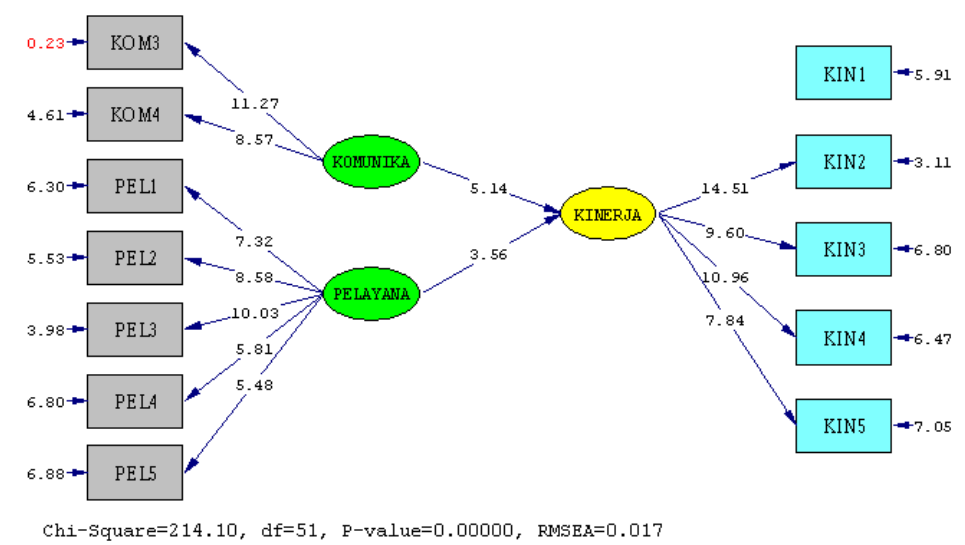

\section{Gambar 4. The Predicted Results of Full Model based on t-value}

Berdasarkan Gambar 4. dapat diketahui bahwa parameter pada Full Model signifikan (nilai thitung yang lebih besar dari 1,96), yaitu Komunikasi terhadap Kinerja dan Pelayanan terhadap Kinerja pada Perawat Rumah Sakit Bhayangkara Palembang, pada taraf 0,05\%.

Hasil analisis full model SEM berdasarkan standar loading ditampilkan pada Gambar 5:

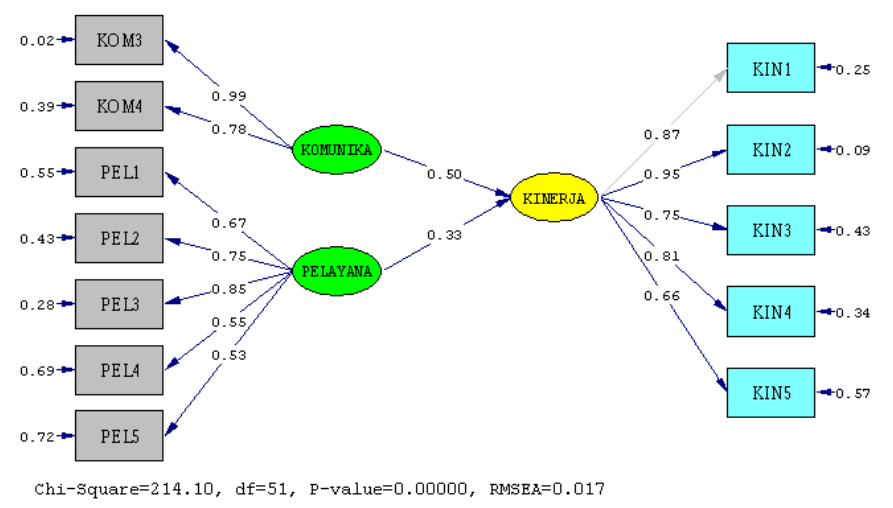

Gambar 5. Basic Model Standardized Solution 
Berdasarkan hasil standar loading di atas, diperoleh persamaan struktural sebagai berikut.

\section{Structural Equation:}

$$
\text { KINERJA = 0.50*KOMUNIKASI + 0.33*PELAYANAN }
$$

Berdasarkan model struktural dapat di jelaskan bahwa Komunikasi terhadap Kinerja Perawat Rumah Sakit Bhayangkara Palembang sebesar 0.50, dan Pelayanan terhadap Kinerja Perawat Rumah Sakit Bhayangkara Palembang sebesar 0.33.

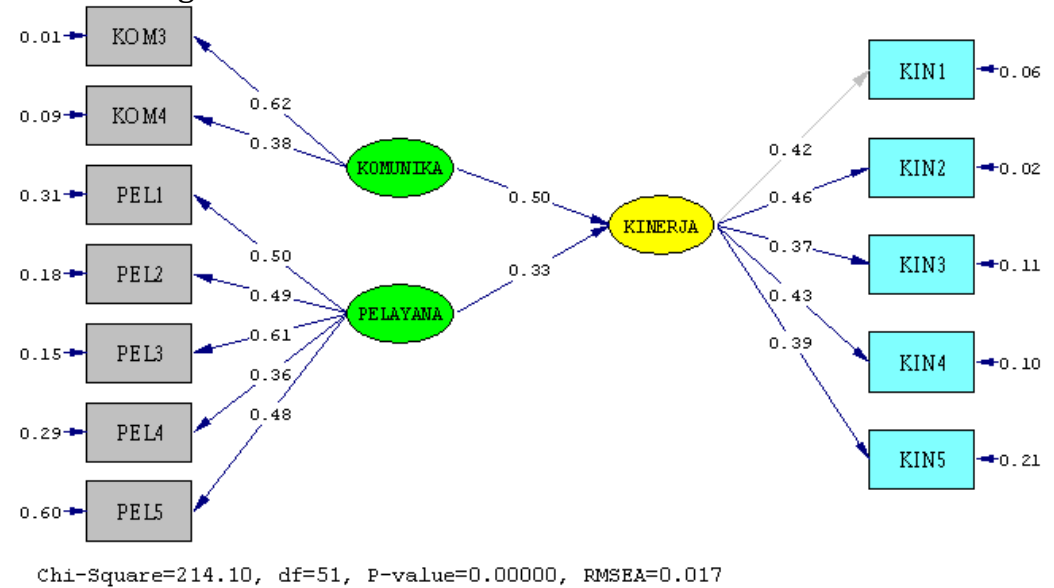

Gambar 6. Struktur Model Estimates

Berdasarkan hasil uji hipotesis yang telah dilakukan, peneliti membuktikan adanya hubungan signifikan pada tingkat keyakitan $95 \%$ dengan $t$-values $>1,96$. Secara umum hasil uji hipotesis dan estimasi seperti pada tabel berikut:

Tabel 5. Uji Hipotesis

\begin{tabular}{lllll}
\hline Hipotesis & Path & t-value & Estimasi & Hasil \\
\hline $\mathrm{H}_{1}$ & KOMUNIKASI $\rightarrow$ KINERJA & 5,14 & 0,50 & Diterima \\
$\mathrm{H}_{2}$ & PELAYANAN $\rightarrow$ KINERJA & 3,56 & 0,33 & Diterima \\
\hline
\end{tabular}

Hipotesis 1 dapat dilihat dari Tabel 5 terbukti diterima karena t-value sebesar 5,14 (tingkat keyakinan 95\%) > 1,96 yang berarti terdapat hubungan signifikan antara variabel Komunikasi terhadap Kinerja Perawat Rumah Sakit Bhayangkara Palembang. Nilai estimasi yang ditunjukan Tabel 5. yaitu sebesar 0,50 menandakan bahwa pengaruh variabel Komunikasi berpengaruh positif dan signifikan terhadap Kinerja Perawat Rumah Sakit Bhayangkara Palembang.

Hipotesis 2 dapat dilihat dari Tabel 5 terbukti diterima karena t-value sebesar 3,56 (tingkat keyakinan 95\%) > 1,96 yang berarti terdapat hubungan signifikan antara variabel Pelayanan terhadap Kinerja Perawat Rumah Sakit Bhayangkara Palembang. Nilai estimasi yang ditunjukan Tabel 5. yaitu sebesar 0,33 menandakan bahwa pengaruh variabel Pelayanan berpengaruh positif dan signifikan terhadap Kinerja pada Perawat Rumah Sakit Bhayangkara Palembang.

\section{Simpulan dan saran}

Dari hasil penelitian ini dapat diambil kesimpulan sebagai berikut : 1 . Variabel Komunikasi dan Pelayanan berpengaruh positif dan signifikan terhadap Kinerja Perawat Rumah Sakit Bhayangkara Palembang dan 2. Variabel Komunikasi berpengaruh lebih dominan terhadap Kinerja Perawat Rumah Sakit Bhayangkara Palembang di bandingkan variabel Pelayanan.

\section{Daftar Rujukan}

Cangara, Hafied. 2007. Pengantar Ilmu Komunikasi. Jakarta: PT. Raja Grapindo Persada.

Ferdinand, A. T. 2005. Structural Equation Modelling. Semarang: Badan Penerbit Universitas Diponegoro. 
Hadiwijaya, Hendra. 2011. "Persepsi Siswa Terhadap Pelayanan Jasa Pendidikan Pada Lembaga Pendidikan El Rahma Palembang." Jurnal Ekonomi dan Informasi Akuntansi (JENIUS) 1(3): 221-37. http://news.palcomtech.com/wp-content/uploads/2012/01/HENDRAHADIWIJAYAJE01032011.pdf.

Hadiwijaya, Hendra. 2015. "Pengaruh Gaya Kepemimpinan Dan Motivasi Terhadap Kinerja Karyawan Pada Unit Usaha Pengembangan Dan Lingkungan PT. Perkebunan Mitra Ogan Baturaja." Jurnal Ekonomi dan Informasi Akuntansi (Jenius) 5(1): 37-56.

Hadiwijaya, Hendra. 2016. "Pengaruh Quality Of Work Life Terhadap Person Organization Fit dan Implikasinya Pada Kinerja Karyawan." Jurnal Manajemen dan Bisnis Sriwijaya 14(4): 439-48. http://ejournal.unsri.ac.id/index.php/jmbs/article/view/4511.

Hadiwijaya, Hendra. 2017a. “Analisis Organization Citizenship Behavior (Ocb) Dan Person Organization Fit(Po-Fit) Terhadap Kinerja Karyawan Bagian Non Medis Rumah Sakit Islam Siti Khodijah Palembang." Jurnal MOTIVASI 2(1): 188-99. http://jurnal.umpalembang.ac.id/index.php/motivasi/article/view/585/529.

Hadiwijaya, Hendra. 2017b. "Pengaruh Kualitas Pelayanan Dan Kepatuhan Bayar Pajak Kendaraan Pribadi Terhadap Kepuasan Pelayanan.” International Journal of Social Science and Business 1(3): 177-85. https://ejournal.undiksha.ac.id/index.php/IJSSB/article/view/11714.

Kotler, Philip. 2000. Manajemen Pemasaran Di Idonesia: Analisis, Perencanaan Implementasi Dan Pengendalian. 1st ed. Jakarta: Salemba Empat.

Marismiati, and Hendra Hadiwijaya. 2013. "Pengaruh Kualitas Pelayanan Terhadap Kepuasan Pelanggan Jasa BRT Transmusi Palembang." Jurnal Ekonomi dan Informasi Akuntansi (JENIUS) 3(1): 268-81. http://news.palcomtech.com/wp-content/uploads/2014/11/MARISMIATIHENDRA-JE030313.pdf.

Mathis, Robert L, and John H. Jackson. 2006. Manajemen Sumber Daya Manusia. Jakarta: Salemba Empat.

Normasari, Selvy. 2013. "Pengaruh Kualitas Pelayanan Terhadap Kepuasan Pelanggan, Citra Perusahaan Dan Loyalitas Pelanggan.” Jurnal Administrasi Bisnis (JAB) 6(2).

Nugroho, Novemy Triyandari. 2014. "Pengaruh Kualitas Pelayanan Terhadap Kepuasan Dan Loyalitas Pelanggan (Survey Pada Pelanggan Speedy Telkom Di Kota Surakarta).” Jurnal Paradigma 12(2).

Prawirosentono, Suryadi. 2008. Kebijakan Kinerja Karyawan. Yogyakarta: BPFE.

Prawirosentono, Suyadi. 2001. Manajemen Operasional: Analisis Dan Studi Kasus. 2nd ed. Jakarta: PT Bumi Aksara.

Rivai, Veithzal. 2006. Manajemen Sumber Daya Manusia Untuk Perusahaan. Jakarta: PT. RajaGrafindo Persada.

Suhaila, Erda ,Susanto, Mahendro Prasetyo Kusumo. 2017. Pengaruh Komunikasi Terapeutik Perawat Terhadap Kepuasan Pasien Di Instalasi Bedah Sentral Rsud Kota Yogyakarta. Proceeding Health Architecture, 1(1) 17 tersedia pada http://mmr.umy.ac.id/artikel/proceeding/

Robbins, P Stephen. 2008. Perilaku Organisasi. Jakarta: Salemba Empat.

Tjiptono, Fandy. 2000. Manajemen Jasa. Yogyakarta: Andi Offset. 